\title{
Integration of Information and Communication Technologies in Enhancing Teaching and Learning
}

\author{
Bandhana Bhasin \\ KCS College of Education for Women, Jammu-India
}

\begin{abstract}
The incorporation of technology into teaching and research is one of the most important challenges for education today. It is time to move beyond the walls of our classrooms to join forces with other institutions and societies to revitalize education. The present paper focuses on the use of technology in teaching-learning process that will greatly contribute to meet student needs for learning anywhere, anytime. Integration of Information and Communication Technologies (ICT) into teaching and learning process is a growing field which has variety of definitions according to different points of view. A very common view asserts that the application of ICT processes should be presented in an integrated way as well as concrete model need to be developed for the teachers in order for the integration process to improve students' learning. Based on the premise that "The integration process should strengthen learning of students", there is a need to present an integrated point of view in the application of these processes and to develop some concrete examples for teachers. Therefore, the main purpose of this study is to develop a model assessing the ICT integration process and helping to improve students' learning.
\end{abstract}

Keywords: Information and Communication Technologies; ICT intregration; Enhancing learning; Educational improvement; Teacher Education

\section{Introduction}

Many scholars agree that at the dawn of the 21st century education delivery should not continue to be as business as usual'. The traditional three Rs-literacy (Reading, Writing, and Arithmetic) is challenged by an unprecedented rapid creation and dissemination of knowledge and information hence the move from an Industrial Society to a Knowledge Society. As Kwando (2007) puts it, the Knowledge Society is the society that knows how to use information. For the effective use of information, one needs more than traditional reading, writing, and arithmetic skills.

Can ICTs help to meet the educational requirements of the digital era? The answer to this question is not straightforward as it may seem. First of all ICTs are not a certain magic wand" that educationists can shake to fix all the educational challenges faced in the current knowledge society. The demands and concerns facing the education enterprise were not created by ICTs and will not be resolved by ICTs either. It is going to be very difficult-if not impossible-for countries to meet the objective of effective learning for all, anywhere and anytime.

Integrating ICT into teaching and learning is not a new concept. For Wang and Woo (2007), it may be as old as other technologies such as radios or televisions. Citing Earle (2002), Wang and 
Woo describe integration as having a sense of completeness or wholeness by which all essential elements of a system are seamlessly combined together to make a whole.

Whilst acknowledging that defining both terms (technology and integration), may drive the problem, Earle (2002) supports the position by Wang and Woo when he argues that integration does not only mean the placement of hardware in classrooms. He further contends that technologies must be pedagogically sound and go beyond information retrieval to problem solving. Let us focus on the three words behind ICT: Information, Communication, and Technology.

Why should ICTs be used in teaching and learning? In answering the question: "Is technological infusion necessary in higher education?" Miller et al. (2000), recognize that technology-based teaching may not be essential in all classes but generally it is most facilitative as a result of providing relevant examples and demonstrations; changing the orientation of the classroom; preparing students for employment; increasing flexibility of delivery; increasing access; and satisfying public demands for efficiency. "The whole purpose of using technology in teaching is to give better value to students" (Miller et al., 2000). This better value should also impact the learners/students performance. The effective utilizations of new technologies in education entail both "assimilation" and "accommodation" processes between the existing and novice pedagogical culture.

Over the past three decades, governments and education systems around the world have regarded the use of information and communications technologies (ICTs) as an important issue for improving the effectiveness of teaching and learning (Plump, Anderson, Law, \& Qualex, 2009). As more and more technologies, such as net books, interactive whiteboards, smart phones and digital video recorders, have become more available and affordable, coupled with the rapid expansion of computer networking capability in educational system, there have been continued research efforts in investigating how teachers can use ICT to facilitate student learning (Lebanon, Robinson, \& McDonough, 2009; Newhouse, Trinidad, \& Clarkson, 2002).

Many models for measuring ICT integration in teaching and learning have been proposed through the years. These models can be grouped into the four categories: learning micro models, ICT-oriented micro models, system models, and population models (Newhouse, Trinidad, \& Clarkson, 2002).

The use of information technology can engage learners in the four-step process as described by Kolb in the book Experiential Learning (1997), where he identifies the steps in the following manner.

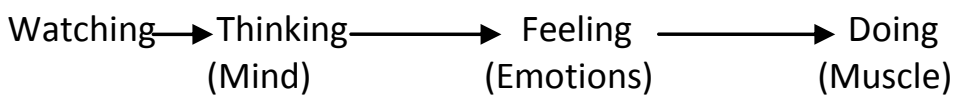

Development in computers, communication, electronics and other multimedia tools provide a wide range of sensory stimuli. It is said 'I hear and I forget, I see and I remember, I do and I understand.' The animations, simulations, software packages to teach various subjects, speech, music, multimedia networks, image enhancements, etc. create virtual realities and experience for the learners, which in turn, help in making learning a more direct, useful, and joyful. Learners' self-engaged learning is conceived as the core of good education 


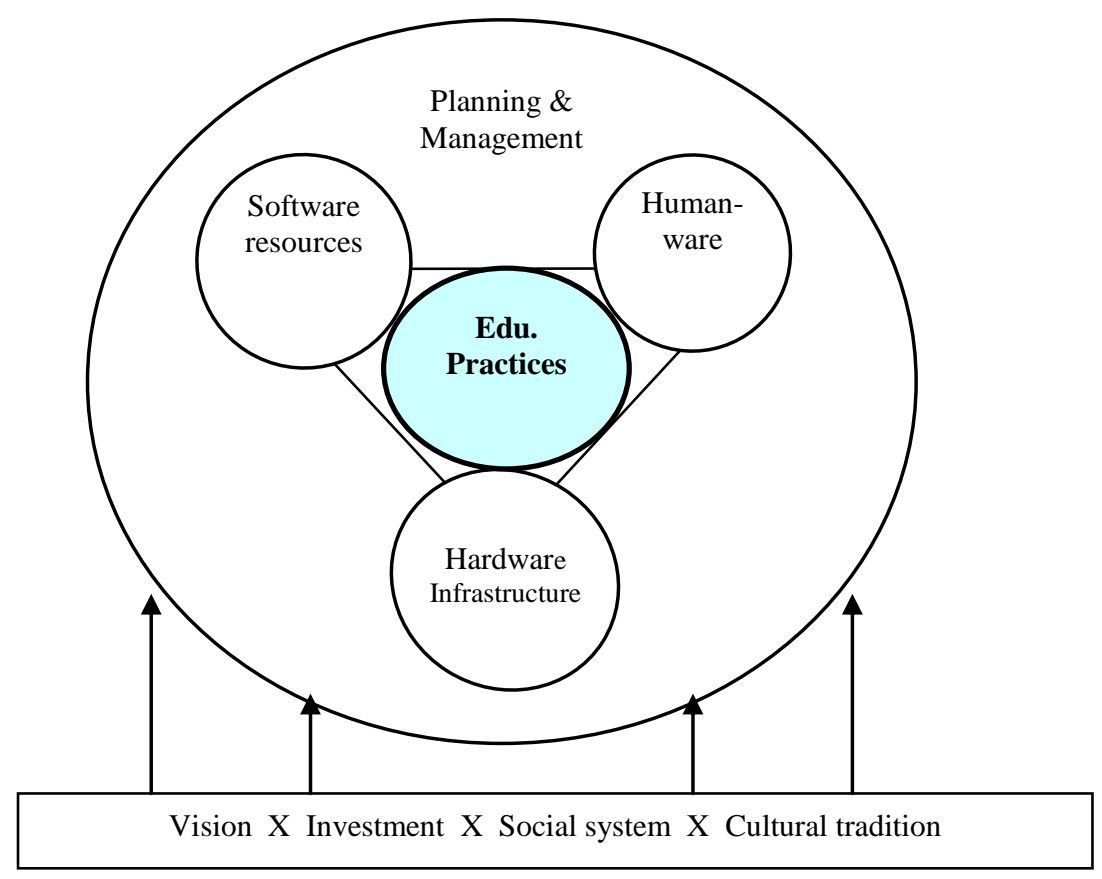

Figure 1. A framework for using ICT to transform education

In the framework, the core circle is the aim of using ICT in education; that is, to improve and transform educational practices by infusing ICT into curriculum and school systems.

(1) Hardware and infrastructure: The construction of hardware and infrastructure facilities is intended to provide learners, teachers and institutions with adequate computers, network connections, related digital equipments (e.g. printers, LCD projectors, and cameras, etc.) and supporting facilities to allow the widening community to benefit from ICT. All these facilities should be able to run smoothly and update based on a regular time cycle.

(2) Software and services: This circle is responsible for providing learners, teachers, and educational institutions with educationally valuable software tools, content resources, and related services. Educational software encloses learning management systems (LMS), course content management systems (CCMS), multimedia and Web-based courseware, learning resources banks, computer assisted testing systems, framework software such as modeling and Micro world environments, educational gateways, educational management systems and other application software. In this era of network, the public service institutions such as libraries, museums, and galleries can extend their rich learning resources and services to wider communities.

(3) Human-ware: Some thirty years ago, the pioneers of CAI research declared with full confidence that computer would bring about the fundamental changes in education. However, we have not yet seen that happens until today. One of the bottleneck factors that constrain the effective integration of ICT in education is supposed to be the weakness in teacher training (Chen, 1996, 1997). The aims of the human-ware circle are to create a professionals that makes effective use of ICT and understand the pedagogic issues. All teachers, technology coordinators, and administrators should 
have chances of professional development to formulate proper understandings of and adequate competencies with the educational uses of ICT. This entails the provision of sustainable pre and in-service training and ongoing job-based performance support.

(4) Systematic planning and management: Using ICT to transform education entails the systematic planning and management to involve and coordinate related public and private sectors, plan, monitor, and regulate the processes, and guarantee the smooth, cost-effective, and sustainable development of ICT in education. This encompasses the planning and managements at the national, regional, and institutional levels.

Integration of Information and Communication Technologies (ICT) into teaching and learning process is a growing field which has variety of definitions according to point of view. Based on the premise that "The integration process should strengthen learning of students", there was a need to present an integrated point of view in the application of these processes and to develop some concrete examples for teachers.

When the literature is overviewed, it seems that the integration of ICT is not a simple application; it is necessitated to contribute to the learning process of the students (Cartwright \& Hammond, 2003; Herzog, 2004; Lim and Chin, 2004; Lim et al., 2003; Roller, 2003). Thus, the answer given to the question "How should ICT be used in the teaching and learning process so that it contributes to the learning of the student?" becomes increasingly important. The answers given to this question may vary according to the point of view on the integration process.

These points of view are generally taken in two groups. The first is the technological point of view, which supports the integration of technological infrastructures and systems into the educational environment; the second is the pedagogical point of view, which supports the integration of ICT materials and programs in terms of social constructivist learning principles (Richards, 2006). The convergence of pedagogical and technological points of view support effective connections between suitable technology for content and pedagogical principles to design learning environments.

Accordingly, teachers need to know why and how to use ICT applications and resources. However, in a study by Usual, Mumu, and Demiraslan (2007), it was observed that although teachers stated that they believe in the benefits of the integration of ICT, they did not know how to realize that. This result brought about concrete sample applications support provided for teachers except in-service training and technical support.

Based on the premise that "The integration process should strengthen learning of students", there is a need to present an integrated point of view in the application of these processes and to develop some concrete examples for teachers. That is why it is stated that the effective use of ICT in lessons depends on the awareness of teachers of the potential of ICT in teaching and learning processes; of appropriate selection of materials for their students; of effective contemplation of their lessons and; of carrying out class management rules while overcoming the difficulties encountered during lessons in which technology supported learning environment (Becker, 2001; Duchateau, 1995; Gobbo \& Girardi, 2001; Herzog, 2004; Milliken \& Barnes, 2002; Sandholtz et al., 1997). These requirements are assessed within the framework of " $5 \mathrm{~W} 1 \mathrm{H}$ " questions and a detailed model is suggested. 


\section{A Unified Model of Integration of ICT Into Teaching and Learning Process}

This model is not a linear model, but a cyclical model. That is to say, whereas questions on "who", "why" and "how" are the primary questions to be answered in the integration process, "how" questions should be answered within the context of "what", "where" and "when". All the structures formed under the guidance of the questions in the model are taken into account, both individually and as a whole.

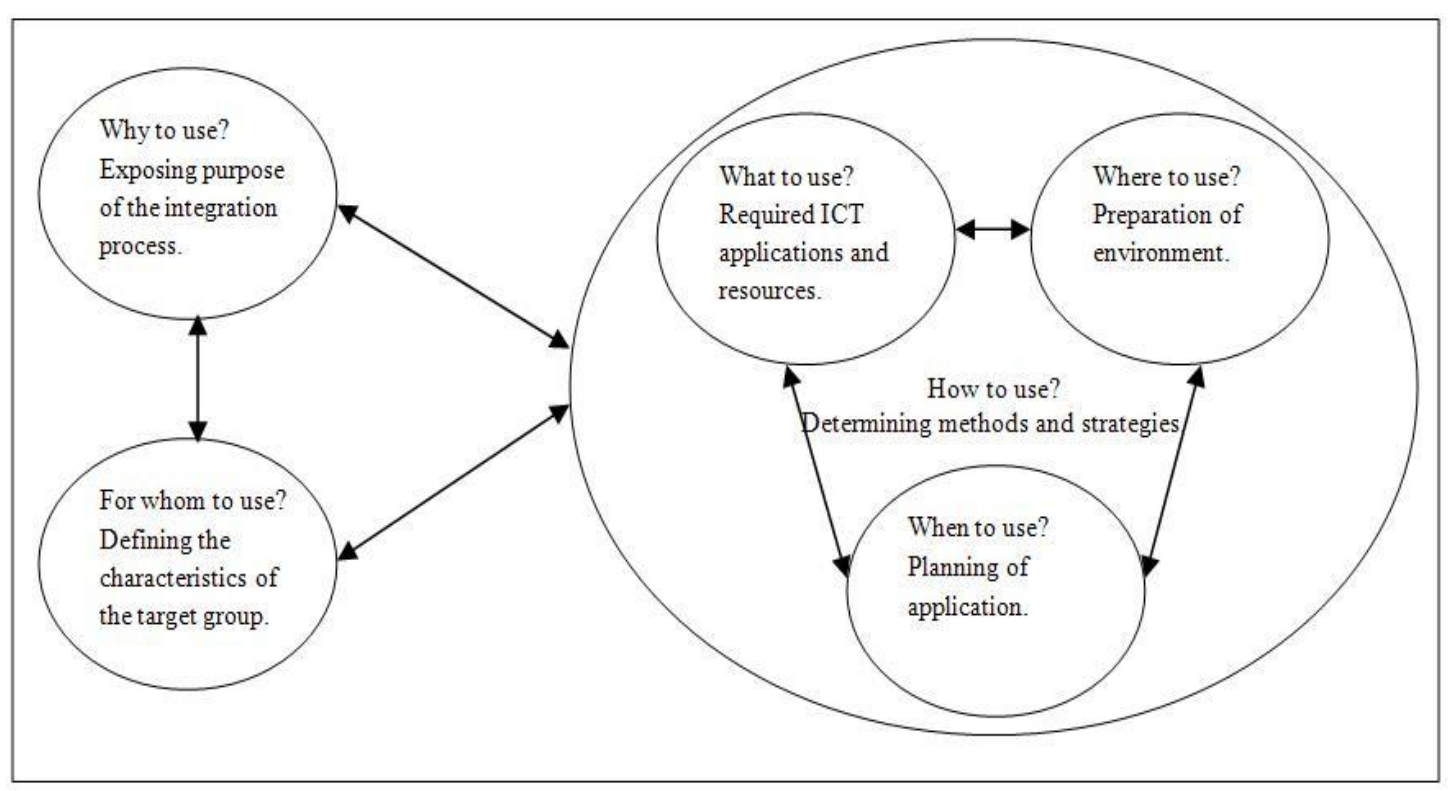

Figure 2. Unified Model of Integration of ICT Into The Teaching- Learning Process

\section{Why? Why should ICT resources and applications be used?}

The answer to this question should focus on the learning of students in terms of pedagogy, technology, and contents' coherence. Therefore, Technological, Pedagogical Content Knowledge (TPCK) framework is defined as:

"TPCK is the basis of good teaching with technology and requires an understanding of the representation of concepts using technologies; pedagogical techniques that utilize technologies in constructive ways to teach content.

On this basis, the answer given to the question "What is the purpose of the integration process?" becomes important. Teachers should be trying to strengthen students' learning by combining appropriate pedagogical approaches and ICT applications and resources in direction of acquisitions of topic.

The answers to "why" question should be looked for within the framework of ICT resources and applications:

- Strengthening the learning process of students

- Carrying out acquisitions of field of subject matter 
- Developing high level learning skills and

- Supporting individual differences of students

\section{Who? For whom shall ICT resources and applications be used?}

The subject of the integration of ICT into teaching and learning process is students or, in other words, they are the learners who are subjected to the integration. For this reason, it is important to determine the characteristics of learners who are the target group of the integration process. Therefore, it is necessary to designate for whom ICT resources and applications shall be used and to identify the characteristics of these users. In addition to cognitive, affective, social, and physiological characteristics of learners, ICT literacy should be taken into consideration.

The answers given to "who" questions should be looked for in:

- ICT literacy of learners

- Interests and necessities of learners

- Individual differences of learners

- Individual characteristics of learners

- Learning strategies of learners

\section{How? How will ICT resources and applications be used?}

In order to prepare and carry out learning environment which is appropriate to the purpose and the characteristics of the target group, the question "How shall ICT resources and applications be used with appropriate teaching methods and learning strategies?" becomes important.

It is also necessary to determine via "how" questions where and when to use the ICT resources and applications in accordance with the teaching methods and learning strategies selected as being appropriate to the content. That is why "how" questions should be taken into account with "what", "when" and "where" questions and their answers:

- Which ICT resources and applications shall be used?

- Where shall selected ICT resources and applications be used?

- When shall selected ICT resources and applications be used?

a. What/Which? Which ICT resources and applications should be used? Answering the question "Which ICT resources and applications would students and teachers benefit from?" is important and for the selection of ICT resources and applications necessary and appropriate for use by teachers in this process.

The answer to "what" or "which" questions should be carefully looked for in selecting ICT resources which are appropriate to:

- Learning strategies

- Teaching methods 
- Evaluation processes

- The individual characteristics of students

b. Where? Where will ICT resources and applications be used? The place where ICT resources and applications are used in the teaching and learning process may be the classroom or laboratory as well as any place out of school such as home, library, scientific centers, museums or online environments. It is more important to prepare the appropriate environment for the integration of ICT into teaching and learning process. Therefore, it is important to find an answer to the question "Where shall ICT resources and application be supplied from and where shall they be used?"

It is important to provide guidance services and support as part of ICT resources and applications. The physical conditions of the environment is crucial, in addition to its user-friendliness and the availability of technical support. The environment where ICT is used should be (a) pedagogically, (b) technically, (c) physically and (d) managerially appropriate.

The answers to "where" questions should be looked for in:

- Where to supply ICT resources and applications from

- Where to use supplied ICT resources and applications

- Where to provide support for the use of ICT resources and applications

- Where students can access ICT resources and applications as well as the necessary support

c. When? When should ICT resources and applications be used?

The answer of the question "When should ICT resources and applications be used?"It is critical for effective lesson-planning and so the applicability of the plan during the integration process of ICT into teaching and learning process.

The answers to "when" question should be looked for in:

- Time and duration of use of ICT resources and applications

- Which ICT resources and application to use and when to use them in accordance with the characteristics of learners

- Time of the use of ICT resources and applications in the evaluation process

\section{Teacher Training and Professional Development}

It is a well known fact that professional teacher development is a key to successful integration of ICT in teaching and learning process. According to Carlson (2002), teachers remain the 
gatekeepers for students' access to educational opportunities afforded by technology: They cannot and should not be ignored. Moreover, providing technical skills training to teachers in the use of technology is not enough. Teachers also need professional development in the pedagogical application of those skills to improve teaching and learning process.

The starting point of a digital classroom is a teacher. Teachers must be trained to effectively use the technology for planning student instruction. The role of the teacher has subtly shifted from being the sole 'provider' of knowledge to being a facilitator as the student explores for himself, the expansive world of knowledge. From being a 'sage on the stage', to being a 'guide by the side'. In today's world, life long learning has become a critical determinant of success. Hence, more than mastering various competencies, the key skill required is learning how to learn. The Learning Management System (LMS) harnesses the potential of technology to improve learning outcomes and to prepare students for the accelerated changes in the world in which they live.

According to the UNDP statistics in the year 2001, almost $80 \%$ of the teachers in developing countries feel that they are not prepared to use the technology. However, efforts are been made to make the teachers aware of the use of technology through pre-service and in-service courses. In addition, Intel ${ }^{\circledR}$ Teach, Edutech programs also aim towards making the teachers techno savvy and teach using the computers. Hence, the use of ICT in teaching requires competencies on part of the teacher and has indeed made the profession more challenging experience and retain knowledge for a longer time

\section{Conclusion}

ICT integration is a comprehensive process of applying technology to the educational system to improve teaching and learning. Its success depends not only on the availability of technology, but also heavily on the pedagogical design. Though there is no one formula for determining the optimal level of ICT integration in the educational system, creative teachers at all levels of education have always found ways to incorporate innovative teaching aids and strategies in their classes. However, ICTs should be used currently in conjunction with well planned classroom teaching.

Jhurree (2005) argues that education reform is occurring throughout the world and one of its tenets is the introduction and integration of ICTs in the education system. The successful integration of ICTs into the classroom warrants careful planning and depends largely on how well policy makers understand and appreciate the dynamics of such integration. Integration of ICTs in education has been a contentious issue (Jhurree, 2005). As Jhurree (2005) claims some people argue that technology will change the educational landscape forever and in ways that will engender a dramatic increase in the performance of learners (Papert, 1997).

Unlike these extreme advocates, there are others who adopt a balanced approach (Jhurree, 2005). They are convinced that ICTs, if properly integrated, have the potential to enhance the teaching and learning (Commission of the European Communities, 2001; Hepp, Hinostroza, Laval, \& Rehbein, 2004; Kozma \& Wagner, 2003; Pelgrum \& Law, 2003; UNESCO, 2003). Levine (1998) emphasizes the importance of having a plan that is based on real school needs and one that is realistic, achievable, and effective. The plan should be produced, not for the sole purpose of putting technology in the classroom but to reflect the real needs of schools in order to make effective technology deployment and to produce enhanced learning environments. 
Hepp, Hinostroza, Laval, and Rehbein (2004) have been cautious to emphasize that there is no universal truth when it comes to applying ICTs in education, and that there is no advice that can be directly applied without considering each country's reality, priorities, and long-term budgetary prospects and commitment. In developing countries ICT should be combined with traditional technologies, such as print and broadcast radio, to achieve better effectiveness (Pelgrum \& Law, 2003).

\section{References}

Becker, H. J. (2001). How are teachers using computers in instruction. Paper presented at the annual meetings of the American Educational Research Association. University of California-Irvine.

Cartwright, V. \& Hammond, M. (2003). The integration and embedding of ICT into the school curriculum: More questions than answers. Paper presented at the ITTE Annual Conference of the Association of Information Technology for Teacher Education. Trinity and All Saints College. Leeds.

Carlson, S. (2002). The missing link in educational technology: Trained teachers. Techknowlogia, October-December 2002. Retrieved on 12 March 2010 from http://www.techknowlogia.org/TKL_Articles/PDF/435.pdf,

Chen, A. Y., Mashhadi, A., Ang, D., \& Harkrider, N. (1999). Cultural issues in the design of technology-enhanced learning systems. British Journal of Educational Technology, 30(3), 217-230.

Commission of European Communities. (2001). Information and communication technologies in development: The role of ICTs in EC development policy. Brussels: Commission of the European Communities. Retrieved on 3 December 2011 from http://europa.eu.int/ $\mathrm{rapid} /$ pressReleasesAction.do?reference $=\mathrm{IP} / 02 / 116 \&$ format $=H T M L \&$ aged $=0 \&$ language $=$ EN\&guilanguage $=e n$

Duchateau, C. (1995). The computer: Ally or alien. In D. Watson and D. Tinsley (Ed.), Integrating information technology into education (pp. 169-185). London: Chapman \& Hall.

Earle, R.S. (2002). The integration of instructional technology into public education: Promises and challenges. ET Magazine, 42(1), 5-13.

Gobbo, C. \& Girardi, M. (2001). Teachers' beliefs and integration of information and communications technology in Italian schools. Journal of Information Technology for Teacher Education, 10(1\&2), 63-84.

Herzig, R. G. M. (2004). Technology and its impact in the classroom. Computers \& Education, 42(2), 111-131.

Haslaman, T., Mumu, K. F., \& Usual, Y. K. (2007). The integration of information and communication technologies in learning and teaching process: A lesson plan example. Education and Science, 32(146), 54-63.

Hepp, K. P., Hinostroza, S. E., Laval, M. E., Rehbein, L. F. (2004). Technology in schools: Education, ICT and the knowledge society. Paris: OECD. Retrieved on 1 December 2011 from http://www1.worldbank.org/education/pdf/ICT_report_oct04a.pdf 
Jhurreev, V. (2005). Technology integration in education in developing countries: Guidelines to policy makers. International Education Journal, 6(4): 467-483. Retrieved on 1 December 2011 from http://ehlt.flinders.edu.au/education/iej/articles/v6n4/jhurree/paper.pdf

Kozma, R. (2002). ICT and educational reform in developed and developing countries. Paris: OECD. Retrieved on 12 November 2011 from http://download.intel.com/ education/wsis/ICT_Education_Reform_Economic_Growth.pdf

Kwando Gambaro, M. (2007). E-learning technologies and its application in higher education: A descriptive comparison of Germany, United Kingdom and United States (Unpublished doctoral dissertation). Maximilians-Universität Munchen.

Lebaron, J., Robinson, J. M. \& McDonough, E. (2009). Research report for Gessometa review of ICT in education phase two. Retrieved on 8 December 2010 from http://www.gesci.org/ assets/files/Research/meta-researchphase2.pdf

Levine, J. (1998). Planning strategically for technology integration. Conference proceedings of the Association for the Advancement of Computing in Education. Retrieved on 17 November 2010 from http://www.coe.uh.edu/insite/elec_pub/HTML1998/el_levi.htm

Lim, C. P. \& Ching C. S. (2004). An activity-theoretical approach to research of ICT integration in Singapore schools: Orienting activities and learner autonomy. Computers and Education, 43, 215-236.

Lim, C. P., Sew, K. M., Hew, T., Wong, P., \& Shanty, D. (2003). Exploring critical aspects of information technologies integration in Singapore schools. Australian Journal of Educational Technology, 19(1), 1-24.

Miller, J., W., Martineau, L. P., \& Clark, R., C. (2000). Technology infusion and higher education: Changing teaching and learning. Innovative Higher Education, 24(3).

Milliken, J. \& Barnes, L. P. (2002). Teaching and technology in higher education: Student perceptions and personal reflections. Computers \& Education, 39(3), 207-317.

Mishap, P. \& Koehler, M. J. (2006). Technological pedagogical content knowledge: A new framework for teacher knowledge. Teachers College Record, 108(6), 1017-1054.

Newhouse, P. C., Trinidad, S., \& Clarkson, B. (2002). Quality pedagogy and effective learning with information and communications technology (ICT): A review of the literature. Retrieved on 8 December 2011 from http:// www.eddept.wa.edu.au/cmis/eval/ downloads/pd/litreview.pdf

Papert, S. (1997). The connected family, bridging the digital generation gap. London: Long Street Press.

Pelgrum, W. J. \& Law, N. (2003). ICT in education around the world: Trends, problems and prospects. UNESCO-International Institute for Educational Planning. Retrieved on 17 November 2011 from http://www.worldcatlibraries.org/wcpa/ow/ 02d077080fcf3210a19afeb4da09e526.html

Plump, T., Anderson, R. E., Law, N., \& Qualex, A. (Eds.) (2009). Cross-national information and communication: technology policies and practices in education (2nd edition). Charlotte, NC: Information Age.

Richards, C. (2006). Towards an integrated framework for designing effective ICT-supported learning environments: The challenge to better link technology and pedagogy. Technology, Pedagogy, and Education, 15(2), 239-255. 
Sandholtz, J. H., Ringstaff, C., \& Dwyer, D. C. (1997). Teaching with technology: Creating student-centered classrooms. New York: Teachers College Press.

UNESCO. (2003). Developing and using indicators of ICT use in education. UNESCOInternational Institute for Educational Planning. Retrieved 15 January 2010 from http://portal.unesco.org/ci/en/ev.php-URL_ID=12438\&URL_DO=DO_TOPIC\&URL_ SECTION=201.html

Usual K. Y., Mumu, K.F., \& Demiraslan, Y. (2007). ICT in the learning-teaching process: Teachers' views on the integration and obstacles. Hacettepe University Journal of Education, 32, 164-179.

Wang, Q. Y., \& Woo, H. L (2007). Systematic planning for ICT integration in topic learning. Educational Technology and Society, 10(1), 148-156. Retrieved on 11 July 2009 fom http://www.ifets.info/journals/10_1/14.pdf

Correspondence: Bandhana Bhasin, Senior Lecturer, KCS College of Education for Women, Jammu, India 